\title{
A TIBEK - mint fúziós információs központ - centripetális hatása a magyar kormányzati döntésekre, különös tekintettel az értékelés és a tájékoztatás szerepére
}

The Centripetal Impact of TIBEK as an Information Fusion Centre on Hungarian Government Decisions, with Special Regard to the Role of Evaluation and Information

A globalizáció hatásai, az új típusú kihivások megjelenése és az internet segitségével kitágított Gutenberg-galaxis alapvető változásokat eredményezett a nemzetközi viszonyokban. Az adatoknak nemcsak a mennyisége nött, de felgyorsult az az idő is, amely alatt azok a felhasználókhoz eljutnak. Az információ értékét egyre inkább az határozza meg, hogy ki és milyen gyorsan szerzi azt meg, illetve a megszerzett információt ki kivel osztja meg. Az egyes államok stabilitását és érdekérvényesitő képességét jelentősen befolyásolja a speciális szervek és szolgálatok által folytatott gyors és precíz tájékoztatás, ugyanakkor a döntésekre egyre kevesebb idő jut. A fúziós információs központok feladata ezért a kormányzati döntéseket megkönnyitő elözetes információgyüjtö, -elemző és tájékoztató tevékenység, amellyel segithetik az időhiánnyal küzdő kormányzatot a precíz és gyors döntések meghozatalában. Bár a fúziós központok története egyelöre rövid, az elmúlt másfél évtizedben mégis gyors fejlödésen mentek keresztül, és alkalmazkodni tudtak az aktuális kihivásokhoz. A TIBEK sikeresen megfelelt az eddig vele szemben támasztott követelményeknek, az új kihivásokra rugalmasan reagálva jelenleg is egy új fejlődési szakasz elött áll.

Kulcsszavak: fúziós központok, centripetális erö, elemzés, elörejelzés, felelösség

Andrékó Gábor a Pécsi Tudományegyetem Földtudományok Doktori Iskola doktori hallgatója. E-mail: gaborandreko@gmail.com 
The effects of globalisation, the emergence of new types of challenges, and the expansion of the Gutenberg galaxy with the help of the Internet have caused profound changes in international relations. Not only has the amount of data increased, but the time it takes to reach users has also accelerated. The value of information is increasingly determined by who obtains it and how quickly, and who shares the information with whom and with whom. The stability and advocacy capacity of individual states is significantly affected by prompt and accurate information provided by specialised bodies and services, but at the same time there is less and less time for decisions. Information fusion centres are therefore tasked with gathering and analysing prior information to facilitate time-consuming government decisions and to help governments make accurate and rapid decisions. Although the history of fusion centres is still short, they have undergone rapid development over the past decade and a half and have been able to adapt to current challenges. TIBEK has successfully met the requirements imposed on it so far, and is now facing a new stage of development by responding flexibly to new challenges.

Keywords: fusion centres, centripetal force, analysis, prognosis, responsibility

\section{Bevezetés}

A 2001. szeptember 11-én az Amerikai Egyesült Államokban végrehajtott nemzetközi, iszlamista eredetű terrortámadások alapjaiban változtatták meg a biztonsági környezetet, és olyan új típusú kihívásként jelentek meg, amellyel szemben naprakész védekezési módszereket kellett kidolgozni. A dzsihád hátterű terror egyesült államokbeli és európai közvetlen megjelenése mellett szembe kellett nézni az internet által kitágított Gutenberg-galaxis nemzetbiztonságot befolyásoló hatásával is. Az internet elterjedésével nem csupán a nemzetbiztonságra veszélyes szervezetek alakítása és cselekményeik összehangolása vált minden korábbi időszakban tapasztaltnál könnyebbé, de az adatok gyakorlatilag azonnali elérhetőségével az időtényező is radikálisan csökkent. A nemzetbiztonsági szolgálatoknak szembe kellett nézniük azzal a problémával, hogy az OSINT²-kutatás kapui ugyan szélesre tárultak, de az információk azonnal hozzáférhetővé is váltak szinte mindenki számára. Erre a komplex helyzetre adott válaszként elsősorban az angolszász és az európai államokban jöttek létre új szervezetként a fúziós központok, ${ }^{3}$ amelyek múködésével és fejlődésük elemzésével kapcsolatos tanulmányok a szeptember 11-i támadásokat mérföldkőként határozzák meg. (A fúziós központok feladata lett az egyes együttmúködő szervezeteknél szétszórtan meglévő információk összegyűjtése és elemzése, amelyek eredményeként képesekké váltak az iszlamista eredetű támadások korai előrejelzésére, illetve

2 Az OSINT (Open Source Intelligence) nyílt forrású hírszerzést jelent. A nyilvános és legálisan hozzáférhető információk bárki által elérhetők, forrásuk lehet az internet, az írott, a nyomtatott és az elektronikus sajtó, de az ingyenes adatbázisok is. A hozzáadott értéket az adatok szűrése, vizsgálata, feldolgozása, elemzése és az összefüggések feltárása jelenti.

3 Cieleszky Péter - Kiss Máté Attila: Ébredő nemzedékek. Nemzetbiztonsági Szemle, 8. (2020), 1. 62-73. 
a döntéshozók számára javaslatokat tudnak tenni az új típusú fenyegetések és hatásaik leküzdésére.) $)^{4}$

A támadások óta eltelt 20 év az új nemzetbiztonsági szervezetek múködését tekintve rövid idő, de már ez alatt is idomultak a feladatok a folyamatosan alakuló világban megjelenő kihívásokhoz. ${ }^{5}$ A 2003-ban az Egyesült Államokban, a Nemzeti Hírszerzés Igazgatójának Hivatala (ODNI) alá rendelt Nemzeti Terrorelhárító Központ (NCTC) ${ }^{6}$ és a brit Egyesített Terrorizmus Elemző Központ (JTAC), ${ }^{7}$ a 2004-ben megalakult spanyol Terrorizmus és Szervezett Bünözés Elleni Hírszerző Központ (CITCO), az olasz Terrorizmus Elleni Stratégiai Elemző Központ (CASA), a holland Nemzeti Biztonsági és Terrorelhárítási Koordinációs Központ (NCTV), majd a 2014-ben létrejött francia Terrorelhárítási Koordinációs Központ (I'UCLAT) fö feladata még a terrorizmus prevenciója volt. Ez a szemléletmód egyébként az újonnan alakult nemzetbiztonsági szervezetek elnevezésében is tetten érhető, a terrorral, illetve az ellene való fellépéssel kapcsolatos jelzővel minden szervezet megkülönbözteti magát az állam egyéb titkosszolgálati szervétől.

Azonban 2010-től, alig tíz évvel a fúziós központok megalakulása után, új szakasz kezdődött ${ }^{8}$ a fúziós központok történetében, mert már további kihívások is hangsúlyosabban jelentek meg. Egyrészt a fő feladat ráirányította a figyelmet arra, hogy a terrorizmus és a szervezett bünözés szorosan kötődik egymáshoz, ezért a terrorizmus elleni tevékenység nem választható el a szervezett bűnözés elleni munka támogatásától. De a terrorfelderítés és a -prevenció hatékonysága a titkosszolgálati információszerzéstől és -elemzéstől sem választható el. A terrorizmus elleni tevékenység, a szervezett búnözés elleni munka és a titkosszolgálati ${ }^{9}$ információelemzés tehát az a hármas egység, amelyet speciális feladat- és hatáskörük miatt a fúziós információs központok össze tudnak fogni. Továbbá a hibrid hadviselés ${ }^{10}$ okozta fenyegetés térnyerésével a tájékoztató-elemző munka szükségképpen fordította figyelmét a befolyásolás problémájára is, mert ez a geopolitikai játszmákban egyre inkább használt módszer a technológia fejlődésével mind a nagyhatalmak (például az USA, Oroszország), mind a regionális hatalmak (például Ukrajna, Szerbia) általánosan kedvelt eszközévé vált.

Cieleszky-Kiss (2020): i. m. 66.

Renske van der Veer - Walle Bos - Liesbeth van der Heide: Fusion Centres in Six European Countries: Emergence, Roles and Challenges. International Centre for Counter-terrorism, 2019.

The National Counterterrorism Center: History (dni.gov). 2021.

Joint Terrorism Analysis Centre: Joint Terrorism Analysis Centre | MI5 - The Security Service. 2021.

Cieleszky-Kiss (2020): i. m.

A titkosszolgálati információk lefedik a biztonságpolitikával, a legális és illegális migrációval, a gazdaságbiztonsággal, a külföldi ellenérdekelt titkosszolgálatokkal és speciális szervekkel, valamint a kiberbiztonsággal kapcsolatos kérdéseket és kihívásokat.

10 Somodi Zoltán - Kiss Álmos Péter: A hibrid hadviselés fogalmának értelmezése a nemzetközi szakirodalomban. Honvédségi Szemle, 147. (2019), 6. 22-28. 


\section{A fúziós központok helye és szerepe az államra ható centripetális erők között}

Az elkövetkező tíz évben várható, hogy a fúziós központok feladatai kiegészülnek, és erősödhet az állam felsővezetése számára azok kül- és belpolitikai döntéselőkészítő szerepe is. Ezt a feladatnövekedést mutatja az a megfigyelhető tendencia, hogy lassan, de töretlenül egyre bővül az ilyen jellegű szervezetek száma. Míg 2001-ben egyetlen fúziós központ sem létezett, addig 2011-re már 72, 2019-re pedig 79 megalakult. ${ }^{11}$ Az államnak egyre inkább szüksége van és lesz olyan szervezetre, amely képes összegyújteni és értékelni az állam különböző szervezeti egységei által megszerzett - nem csak a terrorfenyegetésre vonatkozó - információkat, majd összegezni és tömöríteni a lényegi elemeket a felsővezetői döntés megkönnyítése érdekében. A döntési folyamat azonban itt nem érhet véget, mert felgyorsult világunk és a pontos végrehajtás megköveteli a fúziós központok által feldolgozott és felterjesztett információk alapján meghozott döntések végrehajtói szintre történő visszajuttatását is. Kézenfekvő, hogy ebben a fúziós központoknak nagy szerepe lehet, hiszen az általuk összegzett rendvédelmi, nemzetbiztonsági információkat éppen az általuk múködtetett kommunikációs és tájékoztatási csatorna közvetíti a felsővezetők számára. A feladatelosztás egy része már ma is ugyanezen a csatornán folyik visszafelé, tehát például a magyar fúziós központként működő TIBEK rendszeresen közvetíti az eredeti információbirtokos felé a felsővezetők által az adott információval kapcsolatos konkrét ügyekben kiadott feladatokat.

A fúziós központok tehát a fejlődésük első szakaszainál tartanak, a bennük rejtőző lehetőségek minél hatékonyabb kiaknázása az elkövetkező időszakok feladata lesz. A mindenkori kormány effektív múködése az államszervezetet erősíti, az erős állam pedig a rá ható regionális és nagyhatalmi nyomással szemben eredményesebben tudja védeni a saját nemzeti érdekeit. A kormány eredményességét a modern fúziós központok támogatni tudják, ezért létük és fejlődésük nemzetbiztonsági érdek.

A centrifugális és centripetális erők meghatározását Richard Hartshorne dolgozta ki, ${ }^{12}$ a Hartshorne-modell napjainkhoz igazított kiegészítése pedig Pap Norbert nevéhez füződik. ${ }^{13} \mathrm{~A}$ modell a centrifugális erők alatt az állam egységes szerkezetét romboló hatásokat érti, míg az ezzel szembeni centripetális erők azok a tényezők, amelyek stabilizálják az államszervezetet. Vizsgálja többek között a kisebbségek identitásának erejét, a nyelv és a vallás különbözőségét, a történelmi együttélés hosszát, a kulturális különbségeket, a regionális fejlettségbeli szinteket, de ide sorolhatjuk a nagyhatalmi érdekek jelenlétének befolyásoló hatását is. ${ }^{14} \mathrm{~A}$ tanulmány az államot irányító felsővezetést támogató, a tájékozottságát és ezzel a reagálóképességét növelő fúziós információs központot vizsgálja. Az információk előzetes feldolgozás és szelektálás

Sáfrán József: A Fúziós Központok és alapvető képességeik. Nemzetbiztonsági Szemle, 7. (2019), 4. 83-95. Richard Hartshorne: The Functional Approach in Political Geography. Annals of the Association of American Geographers, 40. (1950), 2. 95-130.

Pap Norbert: Magyarország és a Balkán - kapcsolati terek és helyek. MTA doktori értekezés. 2016.

Andrékó Gábor: Az etnikai és a vallási tényezők centrifugális hatása a szerb és az ukrán államra. Felderítő Szemle, 19. (2020), 3. 127-147. 
után az állam vezetői részére történő továbbításával, és az államszervezeten belül kihasználható szervezési szerepkör felhasználásával a fúziós központ olyan eszközt és egyben centripetális erőt jelent, amelynek kihasználása a modern államszervezet hatékonyságát nagymértékben segítheti.

Hazánk a földrajzi elhelyezkedésének és a geopolitikai viszonyoknak köszönhetően egy olyan pufferzónában (másként ütközőzónában) ${ }^{15}$ található, amelynek különleges jellemzője, hogy nem csupán két nagyhatalom (az EU és Oroszország) peremén fekszik, de a zónában a NATO is jelen van, ezért a NATO-tag nagyhatalom USA érdekei is megmutatkoznak. Mindezeken felül Samuel P. Huntington elméletének megfelelően a pufferzónát egyben egy észak-déli irányú vallási és civilizációs törésvonal ${ }^{16}$ is hosszában kettészeli, ami a zónában lévő államok között a térség vezető szerepéért folyó geopolitikai játszmákat tovább bonyolítja. Az ütközőzónánkba Huntington alapján az alábbi országok, térségek tartoznak: Finnország, Baltikum, Fehéroroszország, Ukrajna, Románia, Moldávia, Bulgária, a V4-országok és az egykori Jugoszlávia területén kialakult utódállamok. A kormányzatot segítő, centripetális erőt jelentő fúziós központok azonban nem minden térségbeli államban alakultak ki, ráadásul ahol kialakultak, az amerikai és a brit szolgálathoz viszonyítva ott is évtizedes lemaradást kell behozniuk a fejlődésben.

Térségünkben a V4-országok hoztak létre fúziós központokat, amelyek közel azonos időben alakultak meg, és a nemzetközi main streamhez hasonlóan fő feladatuk a terrorizmus elleni harcot támogató munka lett. A csoportból elsőként, 2013-ban a szlovák Nemzeti Biztonsági és Elemző Központ (National Security and Analytical Centre - NBAC) jött létre. Ezt követte 2017-ben a cseh Terrorizmus és Hibrid Fenyegetések Elleni Központ (Centre against Terrorism and Hybrid Threats - CTHT) és a magyar Terrorelhárítási Információs és Bünügyi Elemző Központ - TIBEK (Counter-terrorism Information and Criminal Analysis Centre) megalakulása. A lengyel Terrorelhárítási Kiválósági Központ (Terrorism Prevention Centre of Excellence - TPCoE) 2018-ban kezdte meg müködését. Mint látható, a pufferzónában a fúziós központok még kis számban vannak jelen, a meglévők pedig a létezésük rövid ideje miatt fejlődésük elején vannak. A magyar szervezet tehát az amerikai és a nyugat-európai példákhoz viszonyítva aránylag későn, 14 éves elmaradással alakult meg, de a régiót tekintve messze magasabb fejlettségi fokon áll, mint a pufferzóna vezető szerepére potenciálisan törekvő államok hasonló típusú szervezetei. Míg a V4-ek fúziós központjai még fejlődésük legelején tartva (a cseh kivételével, amely a hibrid fenyegetéseket is figyelemmel kíséri) csupán a terrorfenyegetés tényére reagálnak, addig a magyar szervezet már együtt kezeli „a terrorfelderítés - a szervezett bünözés elleni munka - a titkosszolgálati elemzés” hármasát. A TIBEK - és a hasonló V4-es szervezetek - időbeli csúszása ugyanakkor előnyt is jelenthet. A 13-15 éves lemaradás az angolszász fúziós központoktól nem jelent behozhatatlan hátrányt, ráadásul a partnerszolgálatok elmúlt másfél évtizedében szerzett tapasztalatai és az előttük álló kihívások és az azokra adott válaszaik elemzése olyan ismeretekhez segítik az újonnan alakult szervezeteket, amelyek

15 Bernard Cohen szerint: „, $[\mathrm{A}]$ nagyhatalmak versenye által alakított geopolitikai erőterek között lévő stratégiai jelentőségű régió." Bernek Ágnes: Közép-és Kelet-Európa a 21. század geopolitikai/geoökonómiai stratégiáiban. Budapest, Akadémiai Kiadó, 2018. 35.

16 Samuel P. Huntington: A civilizációk összecsapása és a világrend átalakulása. Budapest, Európa, 2014. 
a kezdeti fejlődési szakaszt lerövidíthetik. Regionális előnyt jelent továbbá az is, hogy pufferzónánkban a fent említett négy, fúziós központot létrehozó országon túl további államok egyelőre még nem ismerték fel az információkat összegyűjtő és előzetes feldolgozás alá vonó szervezeti egységek kormányzati döntéshozatalt és szervezeti irányítást segítő jelentőségét, így nem is alkalmazzák azokat. Kézenfekvő, hogy a terrorizmus prevencióját a meglévő titkosszolgálati struktúrájukon belül kezelik ma is, következésképpen nem jutottak el oda, hogy az információk összegyújtése az állam különböző szerveitől nem csupán a terrorral kapcsolatos adatok elemzését jelentheti.

\section{A TIBEK fő jellemzői}

A TIBEK a létezésének eddigi rövid ideje alatt bizonyította, hogy aktívan és eredményesen tudja segíteni a rendvédelmi szervek munkáját, és bűnügyi elemzéssel, speciális elemzői eljárásokkal a szervezett bűnözés elleni munkát is támogatja. A TIBEK feladata megalakulása óta nem korlátozódott csupán a terrorizmus prevenciójára, hanem Magyarország bünügyi és nemzetbiztonsági helyzetét elemző feladatokat is ellátott. ${ }^{17}$ Mint fentebb jeleztem, 2010-től, alig tíz évvel az első fúziós központok megalakulása után, új szakasz kezdődött a szervezett bűnözés elleni munka támogatásával, illetve a hibrid fenyegetés folyamatos növekedése miatti elemző-tájékoztató munka megszervezésével. A magyar fúziós információs központ már a megalakulásakor ezeknek a feladatoknak az ellátására is alkalmas volt.

A TIBEK 2016. július 17-én két szervezeti elemből jött létre a Szervezett Bűnözés Elleni Koordinációs Központ (SZBEKK) - amelynek részei az utasadat-információs egység (PIU) és az azt támogató nyílt forrású információszerző egység (OSINT) - és a Rendészeti Információs Iroda (RII) összeolvasztásával. ${ }^{18}$ Míg a fúziós központoknál kialakult feladatokat figyelembe véve a terror elleni küzdelmet támogató munka, a szervezett bűnözés elleni fellépés segítése és a kiberfenyegetéssel szembeni elemző tevékenység koordinálása alapvetően továbbra is a SZBEKK és a PIU szakmai bázisán folyik, addig a hibrid fenyegetésekkel kapcsolatos, illetve az időközben egyre táguló kormányzati igényeknek megfelelően a kül- és belpolitikai, gazdasági elemzések az RII alapjain szerveződnek. Az OSINT elkerülhetetlenül fontos szerepe a feladatokat végrehajtó egységek támogatásában jelenik meg úgy, hogy mindeközben önálló jelentési, elemző-értékelő feladatai és jogosultságai is vannak. A továbbiakban a Rendészeti Információs Iroda alapjain szervezett tájékoztató, értékelő és elemző munkát, illetve a klasszikus ügyeleti tevékenységen túlmutató elemző-ügyelet fejlődésének néhány aspektusát és feladatainak alakulását vázolom fel.

Az értékelő, elemző és tájékoztató (a továbbiakban feldolgozó) egységhez beérkező információk forrásait a közigazgatási szervek, a rendészeti szervek, a nemzetbiztonsági társ- és partnerszolgálatok és a nyílt anyagok biztosítják. A közigazgatási szervek az olyan hivatalos csatornákat jelentik, amelyek lefedik többek között

\footnotetext{
17 Az 1995. évi CXXV. törvény a nemzetbiztonsági szolgálatokról 8/A. § részletesen szabályozza a Terrorelhárítási Információs és Bűnügyi Elemző Központ feladatait, kormányzati tájékoztató tevékenységét és támogató, koordinációs elemző-értékelő kötelezettségét. Elérhető: https://net.jogtar.hu/jogszabaly?docid=99500125.tv 
a Belügyminisztériumot az irányítása alá tartozó országos hatáskörű szervekkel, ezért az innen összegyűjtött adatok önmagukban jelentős információs vagyont képeznek. A katonai és a polgári nemzetbiztonsági társ- és partnerszolgálatoktól származó információk különös adatkincset jelentenek, amelyek segítségével folyamatosan elemezhető a Magyarországot érintő nemzetbiztonsági és biztonságpolitikai helyzet. Az összegyújtött adatokat a feldolgozó egység szintetizálja, a kormányzati hírigények alapján rangsorolja, és a tájékoztatás formáját a címzetti körhöz és a témához igazítva elkészíti a tájékoztatót. Ennek a munkának a hatékonyságát nagyban segíti, hogy a feldolgozó egység az együttműködő szervek csaknem mindegyikétől vezényelt elemzőkből állt fel, ideértve a rendészeti szerveket és a titkosszolgálatokat is. Így az elemzőket a Terrorelhárítási Központ, az Információs Hivatal, az Alkotmányvédelmi Hivatal, az Országos Rendőr-főkapitányság, az Országos Idegenrendészeti Főigazgatóság és a BM Országos Katasztrófavédelmi Főigazgatóság szakértőiből válogatták össze. A gondosan szelektált elemzői gárda teszi a TIBEK-et unikummá, és segíti elő az információ-fúziós képességet igénylő, rövid határidős feladatok pontos végrehajtását.

A TIBEK értékelő-elemző munkájának alapvető jelentőségét mutatja a központ elemző részlegéhez az együttműködő szervezetektől beérkező információk évről évre növekvő mennyisége. Bár a darabszám önmagában nem ad arra vonatkozó ismeretet, hogy az egyes információk milyen tartalmúak és milyen terjedelmúek, de a növekedés tendenciájára és ütemére igen. Ha az együttmúködő szervezetektől 2018-ban feldolgozásra érkezett információk mennyiségét bázisértéknek tekintjük, akkor 2019-ben az információk azonos nagyságrendűek, 2020 végére pedig 222\%-os növekedést mutatnak. Az értékelő-elemző részleg tájékoztató munkájának elismertségét és az elemzései iránti szükségletek növekedését a kimenő anyagok számában regisztrálható emelkedés mutatja. A 2018-as évet bázisértéknek tekintve 2019-re és 2020-ra az együttműködő szervek és a kormányzat részére készült tájékoztatók mennyisége 127\%-kal nőtt. Darabszámra a kimenő anyagok 2019-ben és 2020-ban hasonló nagyságrendűek, ami mögött a tájékoztató munka folyamatának letisztulása és a tájékoztató anyagok színvonalának további minőségi javulása áll.

\section{Az elemzés és a tájékoztatás felelőssége a döntéselőkészítésben}

A mindenkori állami vezetés a döntései meghozatala előtt támaszkodik az államapparátus szervezeti egységeitől érkező információkra és elemzésekre. Az adatok előzetes értékelésének a kormányzat döntéseinek előkészítésében mindig kiemelt szerepe volt, ezért a helytálló értékelés elkészítésének a felelőssége óriási. Különösen a szélsőséges körülmények hívhatják fel a figyelmet a pontos előkészítés kardinális szerepére.

Klasszikus példaként jól mutatja ezt az 1943-ban, a Il. világháborúban végrehajtott „Vagdalthús” fedőnevü, brit titkosszolgálati akció. ${ }^{19}$ A szövetségesek célja Olaszor-

19 Matthew Gaskill: The amazing Operation Mincemeat: lan Fleming devised a WWII plan to fool the Nazis. The Vintage News, 2018. július 4. 
szág elfoglalása volt, amit a Szicília szigetén végrehajtott partraszállás biztosíthatott. Azonban a sziget hadászati jelentőségét jól ismerve az olasz és a német csapatok nagy erőket állomásoztattak ott, ezért el kellett hitetni velük, hogy a támadás Szardínia szigete ellen fog irányulni. A brit titkosszolgálat egy tiszti egyenruhás tetemet juttatott spanyol felségvizekre olyan dokumentumokkal a táskájában, amelyek arra utaltak, hogy a szövetségesek tartva a németek szicíliai túlerejétől, inkább rövid időn belül Szardínia szigetén szállnak partra. A „megtalált” dokumentumokat a spanyolok eljuttatták német szövetségesükhöz, a német elemzők pedig hitelesnek értékelték az iratokat. A téves helyzetelemzés alapján a Führer utasítására a németek több egységet más hadszíntérre csoportosítottak át, így 1943. július 10-én a szövetségesek szicíliai partraszállásakor (Husky hadmúvelet) csak 200 ezer olasz és két páncélos hadosztálynyi (70 ezer) német katona állt szemben a szövetségesek 160 ezer fő katonájával és 600 tankjával. A sikeres dezinformációnak köszönhetően 38 nap alatt Szicíliát a szövetségesek elfoglalták, és bár 25 ezer főt vesztettek, ez eltörpült a német-olasz haderő 164 ezer fős veszteségével szemben. A brit megtévesztő művelet önmagában nem lett volna képes a német vezetést rossz döntésre bírni, ahhoz a német elemzők hibás helyzetértékelésére és ennek megfelelően a hibás elemzés felterjesztésére volt szükség. A tájékoztatás és elemzés szerepét a döntéselőkészítésben a háborús példa jól megvilágítja, de azok jelentősége nem csak háborús viszonyok között érvényesül.

Napjainkban a nagyhatalmak egyre inkább hajlandók a közöttük már eddig is meglévő ellentétek kapcsán a nyílt konfrontációt felvállalni, s az elemzőknek ebben a környezetben kell helyt állniuk és gondosan ki- és leválogatniuk a dezinformációkat, vagy csupán megtisztítani az alapadatokat az interneten mint kommunikációs csatornában keletkezett zajok ${ }^{20}$ természetes információtorzulásaitól, hogy korrekt helyzetértékelést adhassanak. A források ellenőrzésére, a nagy mennyiségű információ kiválogatására és értelmezésére, valamint a kormányzati hírigényekre adott válasz megalapozottságának fontosságára (illetve az információk politikai manipulációjának lehetőségére) a közelmúltból a Curveball fedőnevű ügyet állíthatjuk példaként.

Az Egyesült Államok által irányított Irak elleni háború 2003-as elindításához George W. Bush kormányzatának olyan titkosszolgálati információkra volt szüksége, amelyekkel az amerikai, de a nemzetközi értelemben vett nyilvánosságot is meg lehetett győzni a fegyveres erő bevetésének szükségességéről. Az amerikai nemzetbiztonsági szolgálatokra ez a politikai elvárás nagy nyomást helyezett, ráadásul az Irak-ellenes invázió mielőbbi megkezdésének igénye az amerikai politikai elit részéről szűk határidőt engedett az információszerzésre és az információ- és forráselemző munkára. Rövid idő alatt nagy mennyiségű adat gyűlt össze, amelyek egymásnak ellentmondtak, ezért alapos ellenőrzésükre volt szükség. A Szaddám Huszein iraki elnök által felügyelt programra vonatkozó információk egy része azt látszott bizonyítani, hogy az iraki rezsim aktívan törekszik tömegpusztító fegyverek előállítására, az invázió mielőbbi elindításának szükségességét pedig azok a hírszerző jelentések voltak hivatottak alátámasztani, amelyek az Irakban titokban kifejlesztett „,mobil biológiai laborokról” szóltak. Az értékelő-elemző munka során az elemzők egyértelmúen kimutatták, hogy a források megbízhatatlanok és ellenőrizetlenek, mert az egybecsengő, tömegpusztító 
fegyverekre és a biológiai laborokra vonatkozó információkat két iraki forrás adta: egy Curveball fedőnevű ügynök és egy Muhammad Harith nevú disszidens. Mindkettejük esetében nyilvánvaló volt az amerikai elvárásoknak való megfelelés kényszere, mert az amerikai kormányzati igényeknek megfelelően használható, kreált információkért cserébe előnyöket reméltek az amerikai szolgálatoktól. Bár rendelkezésre álltak a tömegpusztító fegyverek iraki jelenlétét egyértelműen kizáró nyílt anyagok és titkosszolgálati elemzések, az aktuális amerikai kormányzati érdekek miatt mégis olyan politikai döntés született, hogy a nem ellenőrzött és nem megbízható információkat fogadták el. Az iraki háború lezárultával a CIA végül egyértelműen megbízhatatlannak minősítette a két forrást. ${ }^{21}$ A Curveball fedőnevü ügynök nevével fémjelzett eset ráirányítja a figyelmet a titkosszolgálatokra nehezedő, azonnali válaszokat követelő, a politikai elvárások és az objektív tájékoztatás igénye és követelménye között feszülő időzavar problémájára. Míg a politika a döntései alátámasztásához szükséges háttéradatokat az időtényező minél kisebbre szorításával akarja megkapni, addig a titkosszolgálatok részéről nem elegendő csupán az adott információ minősítése egy másik forrás megerősítésével, mert elengedhetetlen magának a forrásnak az ellenőrzése is, ami viszont összetett és időigényes feladat. Amennyiben a forrás ellenőrzése elmarad, a politika az idő hiányára hivatkozva maga választhatja ki a rendelkezésre álló és megbízhatóságában megkérdőjelezhető információk közül a számára legkedvezőbbet. Az utólag helytelennek minősülő döntések mindig felvetik a titkosszolgálatok felelősségét is, ami jelentős presztízsveszteséget jelent az így kompromittálódott szervezeteknek.

A kormányzat napi döntéshozó munkáját a TIBEK elemző és tájékoztató részlege az ad hoc elemzési feladatok gyors és szakszerű végrehajtásával, a napi jelentőmunkával, a heti és a havi rendszerességű tájékoztatókkal törekszik támogatni. Az egyes jelentéstípusok célja és formája alkalmazkodik a döntéshozó igényeihez, a feldolgozott információk jellegéhez és aktualitásához. Általánosan elmondható, hogy a jelentések témái sokrétűek, de a Magyarországot és a környező országokat érintő olyan fontos események, mint a tömeges migráció alakulása, a korunk halálos betegségeként megjelent Covid-19 terjedése, vagy az ország politikáját, gazdaságát befolyásoló külpolitikai és külgazdasági események folyamatos elemzés tárgyai. A kormányzati hírigények alapján a TIBEK illetékes részlege az együttműködő szervezetektől származó információk és OSINT-kutatás alapján összegyưjti a releváns adatokat, és előzetes elemzést végez. Felgyorsult világunkban egyre meghatározóbb tény, hogy míg a beáramló és előzetes feldolgozásra kerülő adatok száma folyamatosan és drasztikusan nő, addig a kormányzat döntésre jutó ideje vészesen csökken.

A jelentőmunka akkor lehet hatékony, ha nem csupán gyorsan tudja eljuttatni elemzéseit a felhasználóhoz, és az információ aktualitása és súlya is megfelel a döntéselőkészítők igényeinek, de figyelembe veszi azt is, hogy a döntéshozó ideje korlátozott. Hozzá kell őt segíteni ahhoz, hogy a lehető legrövidebb idő alatt átláthassa a számára felterjesztett információhalmaz tartalmát és fontosságát.

Napjainkban többféle jelzésrendszer alakult ki a vezetői időgazdálkodás támogatására. A napi rendszerességú tájékoztatás célja például a felhasználók figyelmének

$21 \quad$ Robert Imre - Stephen Owen: Hírszerzési kudarcok? A hírszerzés politikája. In Merkovity Norbert (szerk.): Politikai kommunikáció-kutatások a közösségi média korában. Szeged, Primaware, 2014. 
felhívása olyan hírekre, amelyek rövid vagy középtávon megoldandó problémaként jelentkezhetnek a kormányzat számára. Ezek a jelzések tömörek, legfeljebb 4-5 sorban ${ }^{22}$ képesek összefoglalni egy-egy kérdés lényegét úgy, hogy a döntéshozó abból azonosítani tudja magát a problémát és annak mértékét. A döntéshozónak lehetősége nyílik arra, hogy a jelzés kézhezvétele után azonnal visszakérdezhessen, kiegészítő jelentést kérhessen az eredeti forrástól közvetlenül vagy a fúziós központ csatornáján keresztül.

Hasonlóan vezetői időgazdálkodást támogató jelzés a heti rendszerességű tájékoztatásban az annota, ${ }^{23}$ amely az összes beérkező információ közül tematikusan összeállított, figyelemfelkeltő jelzéscsokor. A jelzések tömörek, az eredeti adatállomány - amelynek terjedelme pár bekezdéstől akár több száz oldalig terjedhet - lényegét legfeljebb 21-29 sorba sürítve ${ }^{24}$ jelenítik meg. Továbbá az így összegzett tényanyagot maximum négysoros előjelentésbe (magüzenetbe) formálni tovább szúkíti az elemzést az annota előtt, amelynek célja, hogy a döntéshozó rövid idő alatt az annota lényegi mondanivalójának birtokába juthasson anélkül, hogy felesleges időt veszítene a teljes anyag elolvasásával. Amennyiben a négysoros magüzenet a döntéshozó érdeklődését felkeltette, a probléma bővebb tárgyalását megismerheti az annotából, és ha további mélységi ismereteket kíván szerezni az adott témáról, a tájékoztató részlegen keresztül gyorsan bekéretheti a jelzés alapjául szolgáló alapanyagot.

A vezetői időgazdálkodást támogató jelzések különös eleme tehát a négysoros „magüzenet”, amely nagy értékelö-elemzői szakértelmet, a szövegértelmezés magas szintjét és kiemelkedő szintetizálási képességeket követel meg. Az elemző és értékelő szakemberek közül tehát nem mindenki képes a lényegi elemek ilyen léptékú kiszűrésére, az alapvető kvalitás mellett továbbképzés és gyakorlás is szükséges ahhoz, hogy a „magüzenetbe” a leginkább kiemelni való súlyponti gondolatok kerüljenek egy többoldalas anyagból. Mint látható, a fúziós információs központ tájékoztató részlegének felelőssége, hogy a döntéshozó felé egy összetettebb anyagból milyen elemeket, üzeneteket emel ki és hoz látókörbe.

\section{A gyorsaság szerepe a döntéselőkészítésben}

Mint a bevezetőben már jeleztem, a Gutenberg-galaxis az internet rohamos fejlődésével napjainkra felgyorsította az információ áramlásának sebességét, és kitágította a hozzáférhető adatok mennyiségét, de a klasszikus információkutató munkát nem válthatta ki. ${ }^{25} \mathrm{~A}$ különböző keresőmotorok segíthetik az információkutatást, de önmagukban nem mindig képesek automatikusan megtalálni a világhálóra feltett minden információt, amit viszont egy gyakorlott elemző meg tud keresni. Abban is

\footnotetext{
22 A napi tájékoztató formai követelménye, hogy betűtípusa Times New Roman, betűnagysága 12-es, a sorköz szimpla, igazítása pedig sorkizárt.

23 Az annota egy olyan - általában hosszabb - jelentés vagy elemzés tartalmi összegzése, amely tömören adja vissza annak lényegi mondanivalóját, és célja a döntéshozó figyelmének felhívása egy adott problémára.

24 Az annota formai követelménye, hogy betűtípusa Times New Roman, betűnagysága 14-es, a sorköz szimpla, igazítása pedig sorkizárt.

25 Mark Y. Herring: 10 Reasons Why the Internet Is No Substitute for a Library. Winthrop University, Dacus Library Faculty Publications, 2001
} 
széles körű egyetértés mutatkozik az elemzéssel foglalkozó szakemberek között, hogy ugyan az interneten sok információ megtalálható, de korántsem minden. A fentiek, továbbá a döntéselőkészítők folyamatos informáltság iránti igénye együttesen mutatják az elemzésben és az értékelésben az élőerő fontosságát, illetve állítják a TIBEK elé a folyamatos, akkurátus tájékoztatás feladatát.

Az információk állandó figyelemmel kísérésére és előzetes szűrésére, továbbá a 24 órás töretlen tájékoztatásra a TIBEK-nél az ügyeleti szolgálat mutatkozott a legalkalmasabb szervezeti egységnek. Egyrészt már létező szolgálatként rendelkezett a múködtetéséhez szükséges alapállománnyal, másrészt az ügyeleti munka sajátosságai miatt az élőerő 24 órás permanens jelenléte eleve biztosított volt. Az új kihívásnak történő megfelelés érdekében ezért a klasszikus ügyeleti feladatok ellátását ki kellett bővíteni az információkutatást támogató technikai eszközökkel. Ez magában foglalja a korszerű számítógépeket és az interneten adat- és információkutatásra alkalmas keresőszoftvereket. A mindenkori elemző-ügyeleti szolgálat számára a TIBEK lehetővé tette, hogy a világhálóra csatlakozó médiafelületek mellett a különböző adattárakat is szabadon elérhesse és kutathasson benne.

Emellett az állomány részére belső továbbképzéseket is biztosítani kellett, amelyek elvégzésével képessé vált meghatározott elvek és iránymutatás mentén az önálló adatgyűjtésre. A nehézséget kezdetben az is okozta, hogy a klasszikus ügyeleti feladatok nem feltétlenül kívánják meg sem az értékelő-elemző munka szakmai fogásainak ismeretét, sem az idegennyelv-tudást. Ezzel szemben egy fúziós központban nem elegendő csupán egy idegen nyelv ismerete, mert az objektív tájékoztatáshoz a nyomtatott és az elektronikus sajtó minél szélesebb skáláját figyelemmel kell kísérni. A nagy világnyelveken túl a pufferzónánkban lévő államok nyelveit is érteni kell a nagyobb és összetettebb politikai és gazdasági folyamatok, az esetlegesen a magyar érdekeket is befolyásoló tendenciák minél mélyebb megértése és interpretálása érdekében. Ezt a müködtetéssel kapcsolatos alapproblémát a TIBEK tájékoztatással is foglalkozó elemző-ügyeleti szolgálata napjainkra nagyrészt megoldotta. A soron kívüli feladatokra a TIBEK képes a napszaktól és a témakörtől függetlenül rövid idő alatt reagálni, az együttmúködő szervek felé hírigénnyel élni, és érdemben tájékoztatást nyújtani a kormányzati és az együttmúködő szervek részére.

\section{A TIBEK tájékoztató és elemző részlegének további fejlesztési irányai}

A fejlesztés nem állhat le, mert az elmúlt évtizedek folyamán a globalizációnak a politikai, a pénzügyi és a banki kapcsolatokra, a gazdasági, kereskedelmi viszonyokra és a geopolitikai erőviszonyokra gyakorolt hatása szövevényes struktúra kialakulását segítette elő. ${ }^{26}$ A nemzetközi struktúra fejlődésének irányait a globalizációs folyamat alakulása behatárolja, ${ }^{27}$ aminek köszönhetően a földrajzi értelemben Magyarországtól

\footnotetext{
26

Eric Wiebelhaus-Brahm: Globalization, Modernity, and Their Discontents. SSRN Electronic Journal, 2002. augusztus. Szilágyi István: A geopolitika elmélete. Budapest, Pallas Athéné, 2018. 143.
} 
távol eső térségek válságai és fejlődésük problémái is virtuálisan közvetlen közel kerültek, és a mindennapi magyar gazdasági és politikai állapotokra hatással lettek. Az összefüggések felismerése és az okozatok feltárása a megnövekedett hírigények és a növekvő mennyiségú adat leválogatásának szükségessége a TIBEK tájékoztató képességének további mennyiségi és minőségi fejlesztését követeli meg.

Egyrészt a biztonsági kihívások megnövekedése okán - akárcsak a világ többi országában múködő szolgálatoknál - folyamatos szükségszerüségként jelenik meg az elemző-ügyeleti szolgálatba beosztottak létszámának a mindenkori feladatok szakszerű ellátásához szükséges szinten tartása. Ez azért is fontos, mert a fentieken túl a globalizált világ összetett folyamatainak Magyarországra gyakorolt hatásai a társszolgálatok és a kormányzat hírigényének folyamatos bővülését is okozzák, amire gyorsan és szakszerúen kell reagálni. Másrészt a tájékoztató munka nem szúkülhet le a hivatali munkaidőre, továbbá az egyre kifinomultabbá váló hírigények precíz megválaszolása is mélyebb szakértői ismereteket kíván, ezért biztosítani kell a szakértők állandó jelenlétét az információs ügyeleteken.

A fejlesztés másik iránya a munkaminőség szintjének emelése azzal, hogy az elemzések túllépnek a rövid és a középtávú értékeléseken, és a döntéshozó figyelmét felhívják olyan távolabbi időszakban várható veszélyekre és fenyegetésekre, amelyek esetleges negatív hatásainak kivédésére minél előbb fel kell készülni. A KER (azaz Korai Előrejelző Rendszer) a közigazgatási információs rendszerek korrupciós kockázatainak kezelésétől, a kibervédelem helyzetének nyomon követésén keresztül, a természeti katasztrófák lehetséges bekövetkeztének prognosztizálásáig az élet és a köz- és államigazgatás számos területén már alkalmazott intézkedés.

A KER intézménye a megfigyelt folyamat tárgyától függetlenül mindig négy fő elem integrációjából áll, ${ }^{28}$ amelyeknek meg kell felelniük a fúziós információs központok KER-csoportjainak is:

1. A kockázat megismerése: A fúziós információs központ tájékoztatásért felelős szervezeti egységénél a KER-csoport a globalizáció hatásait, ${ }^{29}$ a vezető szerepért régiónkban folyó verseny következményeit és a pufferzóna sajátosságainak szerepét felismerve láthat el speciális feladatot.

2. Folyamatos megfigyelés és előrejelzés: A KER-szakterületen dolgozó elemzők feladata, hogy kutassák fel azokat a Magyarországra (annak gazdaságára, politikájára, társadalmára stb.) közvetlenül vagy közvetve ható folyamatokat, amelyek hazánkra potenciális kockázatot jelenthetnek.

3. Információ felterjesztése: A fúziós központ kommunikációs rendszerét használva a KER-csoport az aktualitás figyelembevételével, a megfelelő időben, részletes jelentést tesz a kormány, illetve az illetékes kormányzati szerv részére. A jelentésében világos és egyértelmű tájékoztatást ad a vizsgált folyamatról és annak Magyarországra kiható következményeiről, a megvalósuló kockázatokról és fenyegetésekről.

4. Válaszreakció: A fúziós központ KER-csoportjának szükség esetén képesnek kell lennie arra, hogy részt vállaljon a megfelelő cselekvési tervek elkészítéséért

\footnotetext{
28 Veronica F. Grasso: Early Warning Systems: State-of-Art Analysis and Future Directions. Draft report, United Nations Environment Programme (UNEP), 2009. 3. Elérhető:

29 Bayer József: A globalizáció és a 21. század geopolitikai kihívásai. Geopolitika a 21. században, 1. (2013), 1. 1-24.
} 
felelős szervezetek és a kormányzat közötti koordináció biztosításában, a végrehajtás koordinálásában.

Ahhoz, hogy a KER-csoport professzionálisan elláthassa a feladatát, megfelelően kiképzett és az aktuális geopolitikai folyamatokat és elméleteket jól ismerő elemzői állományra van szükség. A kutatás tárgyát képező kockázatok távlati jellege miatt nem szükséges, hogy a feladatot ellátó szakértők létszáma nagy legyen, de a folyamatos szakmai képzésekkel biztosítani és támogatni kell a tagok naprakész ismereteinek karbantartását.

\section{7. Összegzés}

Az információs fúziós központként 2016-ban létrejött TIBEK a nemzetközi viszonylatban kialakult hasonló szervezetekhez képest 14 év késéssel alakult meg, de már a kezdetektől hatékonyan segítette a magyar kormányzat döntéselőkészítő munkáját a terrorfenyegetések felderítésére irányuló elemzésekkel, a szervezett bűnözés elleni munka támogatásával és a hibrid fenyegetések fennállását kimutató munkájával. A nemzetközi szinten is rövid ideje működő fúziós központok feladatai már az elmúlt csaknem két évtizedben is rugalmasan alkalmazkodtak az újonnan felmerülő kihívásokhoz. A feladatok megváltozása alapján már legalább két fejlődési szakaszt látunk körvonalazódni. Az első az angolszász szervezetek megalakulásától számítva hozzávetőleg egy évtizedet ölel fel, amely során a feladat a terrorfenyegetések előrejelzésére és az illetékes szervekkel folytatott együttmüködésre fókuszált. A második szakasz még jelenleg is tart, amely során egyre több fúziós központ feladatai terjednek ki a szervezett bűnözés és a hibrid fenyegetések elleni preventív értékelő és elemző munkára. A harmadik fázis, megítélésem szerint, napjainkban kezd kibontakozni. A hibrid fenyegetések talaján szerteágaznak az új kihívások, amelyekre minden fúziós információs központnak válaszolnia kell. A mindenkori kormányzatok munkáját a modern és korszerü központok széles körü elemző és értékelő anyagokkal tudják támogatni, ami a napjainkban is folyamatosan változó globalizáció körülményei között a kormányzatot gyorsabb döntéshozásra és precízebb reagálásra teszi képessé. A jól múködő TIBEK centripetális erőként jelentős mértékben hozzájárulhat az állam stabilitásának fenntartásához és regionális érdekérvényesítő törekvéseinek biztosításához.

\section{Felhasznált irodalom}

Andrékó Gábor: Az etnikai és a vallási tényezők centrifugális hatása a szerb és az ukrán államra. Felderítő Szemle, 19. (2020), 3. 127-147. Online: www.knbsz.gov.hu/hu/ letoltes/fsz/2020-3.pdf

Bayer József: A globalizáció és a 21. század geopolitikai kihívásai. Geopolitika a 21. században, 1. (2013), 1. 1-24. Online: www.pannonpalatinus.hu/wp-content/uploads/2011/12/Bayer-J\%C3\%B3zsef-Geopolitika-I\%C3\%A9vf-1sz\%C3\%A1m.pdf 
ANDRÉKÓ GÁBOR: A TIBEK - mint fúziós információs központ...

Bernek Ágnes: Közép-és Kelet-Európa a 21. század geopolitikai/geoökonómiai stratégiáiban. Budapest, Akadémiai Kiadó, 2018. Online: https://doi. org/10.1556/9789634541783

Cieleszky Péter - Kiss Máté Attila: Ébredő nemzedékek. Nemzetbiztonsági Szemle, 8. (2020), 1. 62-73. Online: https://doi.org/10.32561/nsz.2020.1.4

Deák Csaba: A kommunikáció zavarai. Magyar Grafika, (2003), 1. 38-40. Online: http://real.mtak.hu/42461/1/Deak_Kommunikacio_zavarai_IN_Magyar_ Grafika_2003_01_sz_038_040_old.pdf

Drusza, Tamás (2018): A szervezeti kultúra jelentősége a generációs kihívás és a nemzetbiztonsági szolgálatok fejlesztése szempontjából. Nemzetbiztonsági Szemle, 2018. 6. évf. 2. sz., p. 69-89. Elérhető: https://folyoirat.ludovika.hu/index.php/ nbsz/article/view/1591/905 (A letöltés dátuma: 2021.06.03.)

Gaskill, Matthew: The amazing Operation Mincemeat: Ian Fleming devised a WWII plan to fool the Nazis. The Vintage News, 2018. július 4. Online: www.thevintagenews.com/2018/07/04/operation-mincemeat/

Grasso, Veronica F.: Early Warning Systems: State-of-Art Analysis and Future Directions. Draft report, United Nations Environment Programme (UNEP), 2009. Online: https://na.unep.net/geas/docs/Early_Warning_System_Report.pdf

Hartshorne, Richard: The Functional Approach in Political Geography. Annals of the Association of American Geographers, 40. (1950), 2. 95-130. Online: https://doi. org/10.1080/00045605009352027

Herring, Mark Y.: 10 Reasons Why the Internet Is No Substitute for a Library. Winthrop University, Dacus Library Faculty Publications, 2001. Online: https://core.ac.uk/ download/pdf/214401804.pdf

Huntington, Samuel P.: A civilizációk összecsapása és a világrend átalakulása. Budapest, Európa, 2014.

Joint Terrorism Analysis Centre, 2021. Online: www.mi5.gov.uk/joint-terrorism-analysis-centre

Pap Norbert 2016: Magyarország és a Balkán - kapcsolati terek és helyek. MTA doktori értekezés, 2016. Online: http://real-d.mtak.hu/953/7/dc_1261_16_doktori_mu.pdf

Veer, Renske van der - Walle Bos - Liesbeth van der Heide: Fusion Centres in Six European Countries: Emergence, Roles and Challenges. International Centre for Counter-terrorism, 2019. Online: www.jstor.org/stable/resrep19629?seq=5\#metadata_info_tab_contents

Robert Imre - Stephen Owen: Hírszerzési kudarcok? A hírszerzés politikája. In Merkovity Norbert (szerk.): Politikai kommunikáció-kutatások a közösségi média korában. Szeged, Primaware, 2014. Online: http://publicatio.bibl.u-szeged. hu/4431/1/Politikai\%20kommunik\%C3\%A1ci\%C3\%B3-kutat\%C3\%A1sok\%20 a\%20k\%C3\%B6z\%C3\%B6ss\%C3\%A9gi\%20m\%C3\%A9dia\%20kor\%C3\%A1ban.pdf

Sáfrán József: A Fúziós Központok és alapvető képességeik. Nemzetbiztonsági Szemle,

7. (2019), 4. 83-95. Online: https://doi.org/10.32561/nsz.2019.4.7

Somodi Zoltán - Kiss Álmos Péter: A hibrid hadviselés fogalmának értelmezése a nemzetközi szakirodalomban. Honvédségi Szemle, 147. (2019), 6. 22-28. Online: https://doi.org/10.35926/HSZ.2019.6.2

Szilágyi István: A geopolitika elmélete. Budapest, Pallas Athéné, 2018. 
The National Counterterrorism Center, 2021. Online: www.dni.gov/index.php/nctcwho-we-are/history

Wiebelhaus-Brahm, Eric: Globalization, Modernity, and Their Discontents. SSRN Electronic Journal, 2002. augusztus. Online: https://doi.org/10.2139/ssrn.1666871

\section{Jogi forrás}

1995. évi CXXV. törvény a nemzetbiztonsági szolgálatokról 